\title{
Future challenges of accounting education at the University of Debrecen
}

\author{
Ildikó Orbán ${ }^{1 \mathrm{a}}$, Ágota Kiss ${ }^{1}$, and Zoltán Bács ${ }^{1}$ \\ ${ }^{1}$ University of Debrecen, Institute of Accounting and Finance, H-4032 Debrecen, Hungary
}

\begin{abstract}
The actuality of our research is given by the fact that in the $21 \mathrm{st}$ century, the field of accounting is changing continuously and rapidly. Thanks to the global processes occurred over the last few decades, changes took place in the economic processes and the area of accounting was formed much as well. Nowadays, a lot of undertakings perform such activities, which are cross-border and building international connections up. The differing content and rules of the statements applied in different countries make the comparability and the performance measurement more difficult, particularly for the undertakings, their owners, their existing and potential investors, other decision-makers as well as authorities. The above-mentioned differing application of the accountancy enhances the necessity for establishing a uniform harmonized accounting system, which is unanimous worldwide as well. International Financial Reporting Standards (hereinafter: IFRS) are intended to make the financial reports more transparent and unequivocal for its users; it helps to understand the content of reports and makes the decision-making more open and more predictable. However, we need to be attentive not only to the benefits of unification efforts but the economic, cultural, traditional and legislative differences of the single nations and the difficulties of adopting the different and unusual norms The task of accounting is to give a true and fair image about the property, income and financial situation of an undertaking. Information provided by accounting is essential for both the management decision-making and the market operators. In the frame of accounting education, financial accounting has to deal with SAP Financial Accounting. SAP is the most popular enterprise business system used by the biggest organisations in the world to help run their companies. At the university, our teaching task is to give the knowledge and skills to the students they need in the practical, entrepreneurial life with training courses, education programs. At the University of Debrecen, the Institute of Accounting and Finance is faced with these educational challenges, such as introduction of SAP, and IFRS into the BA and MA education, and by using these systems to support managerial decision-making process and the management accounting. The purpose of this research is to examine how can the education reflect to the worldwide changes, and what is the mainstream in the accounting education nowadays. In order that the leaders
\end{abstract}

\footnotetext{
${ }^{a}$ Corresponding author: orban.ildiko@econ.unideb.hu
} 
of the businesses can make quick and appropriate economic decisions, it is essential in this intensively changing world that an enterprise should have a well-functioning accounting system based on up-to-date information. and that the university can teach new, practical knowledge.

Keywords: international financial reporting system (IFRS); sap; managerial accounting; accounting education

\section{Introduction}

University of Debrecen works in 7 campuses (5 in Debrecen, 1 in Nyíregyháza and Hajdúböszörmény), it has close to 30,000 students (of which 3700 are international students), 1400 lecturers (21:1 student: lecturer ratio), 15 faculties (medical and health sciences, agriculture, food and environmental sciences, arts, natural, social, computer sciences). By the QS ranking 2014: University of Debrecen is among the top 600 in world ranking. In the field of education we have 65 undergraduate majors, 24 graduate majors, 144 postgraduate specialist trainings and 25 doctoral schools. As Research University, it has got University of National Excellence 2013, and it has 25 doctoral schools, Talent management programme, 6 spin-off companies, 55 patent families. The focus areas: pharmaceutical research, food science, and medical biology.

One of the 15 faculties, the Faculty of Economics and Business was founded on 1 August 2014 with the merger of the Faculty of Applied Economics and Rural Development and the Faculty of Economics and Business Administration. This is the biggest Faculty at the University of Debrecen concerning the number of students (4280). The education is conducted by 121 instructors. The Faculty is located at the Böszörményi road Campus. The education is organized by 10 Institutes. The Faculty offers 6 higher education vocational degree, 8 bachelor degree and 10 master degree programmes.

Among the bachelor degree programme (BSc/BA) we can find business administration and management, commerce and marketing, international business, finance and accounting, tourism and catering, the master programmes are in the fields of study in Economics and Business (4 semesters) such as Logistic Manager Master Degree Programme, Master of Business Administration Master Degree Programme, International Economy and Business Master Degree Programme, Accountancy Master Degree Programme, Business Development Master Degree Programme, Management and Leadership Master Degree Programme.

As we can see in the above mentioned list, the Faculty has two programmes in the field of accountancy, a bachelor, named Finance and accounting, and a master degree programme named Accountancy. The Institute of Accounting and Finance is the host of these two programmes, this is why we are committed to develop the accounting education, and give practical and uptodate knowledge to the students. Subject topics contain for example International Accounting Systems - International Financial Reporting Standards, Strategic Managerial Accounting, Application and usage of SAP systems. These are the mainstreams in the accountancy education development, and the topic of our article.

\subsection{International financial reporting standards (IFRS)}

Thanks to the global processes occurred over the last few decades, changes took place in the economic processes and the area of accounting was formed much as well. Nowadays, a lot of undertakings perform such activities which are cross-border and building international connections up. We need to ensure the comparability in order that a foreign partner, investor or creditor can get to know the property, financial and income position of 
an undertaking. The financial statements to be prepared annually by the undertakings reflect the international rules of the firms' own country. This requires a greater attention in that case if the company is also in the international life. The differing content and rules of the statements applied in different countries make the comparability and the performance measurement more difficult, particularly for the undertakings, their owners, their existing and potential investors, other decision-makers as well as authorities. The above-mentioned differing application of the accountancy enhances the necessity for establishing a uniform harmonized accounting system which is unanimous worldwide as well. It makes the financial reports more transparent and unequivocal for its users; it helps to understand the content of reports and makes the decision-making more open and more predictable. However, we need to be attentive not only to the benefits of unification efforts but the economic, cultural, traditional and legislative differences of the single nations and the difficulties of adopting the different and unusual norms

In 2001, the International Financial Reporting Standards (IFRS) replaced the International Accounting Standards to be applied in the period between 1973 and 2001. Since 1st January 2005, the EU's and EEA's (European Economic Association) companies, banks, financial institutions, insurants and their subsidiaries, which are quoted on the stock market, have been obliged to apply the IFRS. It means that these ones have to prepare consolidated (contracted) financial statements according to the International Accounting Standards (hereinafter IAS)/IFRS (Regulation (EC) 1606/2002). Since 2007, this regulation has been binding for those undertakings which trade only with debt instruments on the stock market. Thus, the firms trading with equity securities on the stock exchange are obliged to complete their consolidated accounts according to IFRS since 2005. Aim of IFRS is to ensure the comparability of corporate performances, [4]. In case of some Member States, there are opportunities to prepare consolidated and individual financial statements for firms not quoted on the stock market, in accordance with IFRS.

The basics of IFRS are formed by the Framework. The Framework focuses on not only the financial reports but it lays down the basics of the whole financial reporting. Based on this, we can tell that the aim of financial statements is to give useful information about a company to the capital investors and potential creditors in order that they will be able to make decisions about the resources to be provided for a company, [2].

Instead of determining the value of an undertaking exactly, the specific task of Financial Reporting is to try to give a clue for estimating the market value of an undertaking. In addition to the primary users, the general purpose financial statements can also be useful for the management of undertaking, the economic regulators and other business partners in spite of the fact that the financial statements are not primarily prepared for them. During the completion of financial statements, it can be told that concrete numbers and amounts are not always available; that is the time when there is need for an estimation and individual judgment, the basics of which are laid down by the Framework, [2].

The Hungarian equivalent of the financial statement is the report. It was necessary to create standards relating to the international accounting rules in order to make the completed reports/statements comparable. The following items can be found within standard frame of Presentation of Financial Statements, (hereinafter IAS1): principles to be applied during the international accounting, general information and the regulations regarding structure and content of the financial statements. The aim of financial statements is to prove the efficiency of a managing entity therefore it presents in great detail, among others, the assets, liabilities, equity, revenues and expenditures of the managing entity. Objective of financial reporting is to provide financial information about the reporting entity that is useful to existing and potential investors, lenders and other creditors in making decisions about providing resources to the entity. 
Based on these, as in the Hungarian accounting regulation as well, the financial statements consist of several elements which are the following, [2] :

- statement of financial position as at the end of the period (SFP, or BS as balance sheet),

- statement of profit or loss and other comprehensive income $(\mathrm{P} / \mathrm{L}+\mathrm{OCI})$,

- statement of changes in the equity for the period (SOCIE),

- statement of cash flows ,

- notes.

A number of different measurement bases are employed to different degrees and in varying combinations in financial statements, including

- historical cost

- current cost

- realisable (settlement) value

- present value (CF.4.55)

In the frame of fair value management concept fair value is the price that would be received to sell an asset or paid to transfer a liability (exit price) in an orderly transaction (not a forced sale) between market participants (market-based view) at the measurement date (current price). (IFRS13) Fair value is a market-based measurement (it is not an entityspecific measurement), consequently, the entity's intention to hold an asset or to settle or otherwise fulfil a liability is not relevant when measuring fair value, [1].

The most important demand on the financial statements is the fair presentation. This expectation is helped by that if a managing entity suitably chooses its accounting policy, if a detailed, not numerical but text presentation of the events deemed important are touched upon in the notes and if the principle of materiality, reliability, comparability and comprehensibility. Following the principle of clarity, there are such items which can be detailed free. With regard to all elements of the financial statements, only a minimal content is specified by IFRS. The IAS1 standard deals with presentation only, not with assessment. This large space can be either benefit or disadvantage for a managing entity since the completion of statement requires more attention in the absence of specific content elements, [7].

\subsection{New ways in managerial accounting and controlling}

Thus, financial accounting is concerned with providing information to stockholders, government agencies, creditors, and others who are outside the organization, the form of this information is the annual report. Managerial accounting, in contrast, is intended primarily to supply knowledge to decision makers within an organization. Managerial accounting, or management accounting, is a collection of practices and techniques, which aimed at providing managers with information about the financial position of the entity to help them make decisions and maintain effective and real control over company's resources. For example, managerial accounting answers questions such as: What is the company's average cost per unit (of product or labor)? What is the required rate of return to make a new investment worthwhile? Which activities, products require the greatest expenditures and which earn the greatest profit?

Main difference between financial and managerial accounting is that financial accounting procedures generally must conform to external standards, such as IFRS (which was under inspection in the former chapter), while management accounting methods are left almost completely to the discretion of individual organizations.

In the economic environment of today, it is very important for a production company to have the most possible accurate knowledge about costs, and trends of the corporate activity. This informational demand emerges in case of more and more managing entities since the 
cost cutback is often the only tool for retaining the competitiveness. There is a frequent question among the corporate owners and management: How could our costs be cut to a small extent? One of the devices is the moderation of the activity costs, in order to do this it is essential to know how much the production of the unit of product costs for the company, that is to say, how many its first cost is, [3].

One of the goals of the Insitute of Accounting and Finance is to aim the attention at values and importance of the management information system as well as information obtained during determination of the cost, the differences in results of the individual cost calculation methods and the reasons of differences.

Table 2: New calculation methods, Source: Laáb, 2011

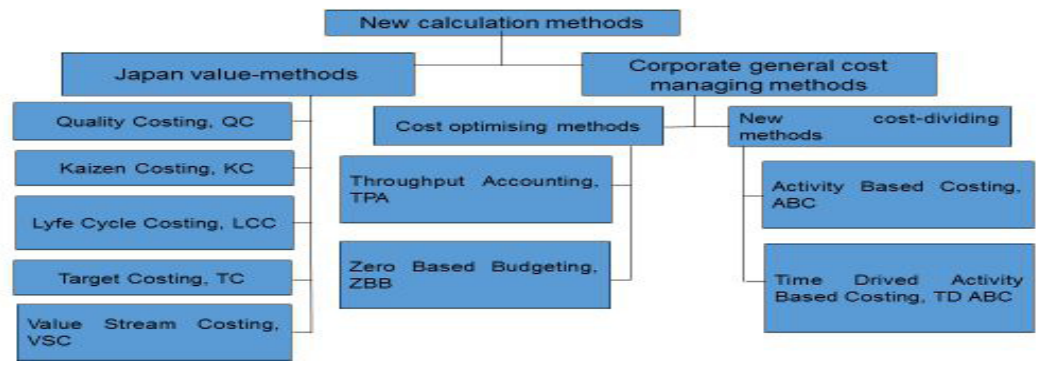

New directions for managerial accounting are the results that there were significant advances in automating routine transaction-related accounting tasks. The Table 2 shows new calculation methods in managerial accounting such as Japan value methods (like Kaizen costing, VSC, etc), and corporate general cost methods (TPA, TD ABC) .

In our education strategy, the Institute of Accounting and Finance deals with new methods on financial and managerial accounting in order to give up-to-date knowledge to our student.

\subsection{The SAP system}

SAP was founded in 1972 by five IBM colleagues. The SAP is an acronym: Systems, Applications, and Products. Today, SAP is the number one business in enterprise computing and is still the third-largest software company in the world, [5]. The company produces business solutions for a wide variety of industries in every major market in the world. SAP's approach to developing software has become even more collaborative, in that it works with business partners to develop product features to reflect real-world computing needs. In addition, SAP has made strong movement to become the leader in several different areas that are becoming more important to businesses in today's ever-changing economy, [5].

In the list of the SAP category application we can see, that the system gives solutions to the financial accounting and the management accounting as well, so it can help the companies, and also the university education to give a proper, worldwide, useful system and knowledge in these fields. We think that the system is able to represent the ITsupported accountancy in the university education.

The SAP offers some educational programmes as well. For example the SAP ${ }^{\circledR}$ University Alliances program and the SAP ® Education institute give opportunity to the students learning economics and engineering that they can participate a training programme which gives SAP certificate at the end of the training. These kinds of cooperation's can be a good challenge to the university education. 


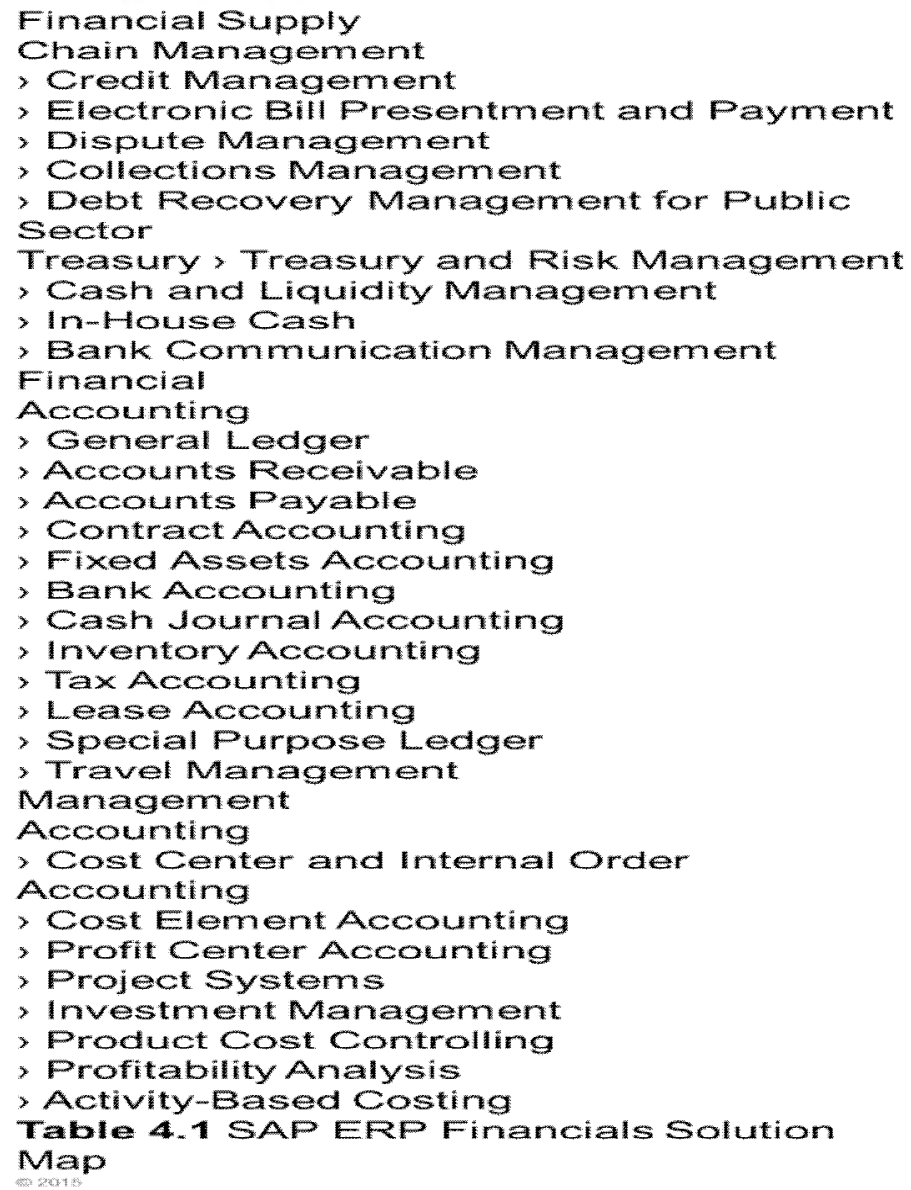

\section{Conclusions}

At the University of Debrecen, the Institute of Accounting and Finance is faced with some educational challenges, such as introduction of SAP, the world leader IT-supported accountancy system, and IFRS (International Financial Reporting Standards) into the BA and MA education, and by using these systems to support managerial decision-making process and the management accounting.

The purpose of this research was to examine how can the education reflect to the worldwide changes, and what is the mainstream in the accounting education nowadays. In order that the leaders of the businesses can make quick and appropriate economic decisions, it is essential in this intensively changing world that an enterprise should have a wellfunctioning accounting system based on up-to-date information. Our aim is that the university can teach new, practical knowledge, and maintain the educational leader role in the Eastern Region of Hungary. 


\section{References}

1. Bartha Á. - Gellért H. - Madarasiné Szirmai A. (2013): Nemzetközi számviteli ismeretek. Perfekt Gazdasági Tanácsadó, Oktató és Kiadó Zártkörüen Működő Részvénytársaság, Budapest, 160-165 p. (ISBN: 978-963-394-824-8)

2. Beke J., Nemzetközi számvitel. Akadémia Kiadó, Budapest, 29-168 p. (ISBN: 978963 059572 8), (2014).

3. Fenyves, V. - Tarnóczi, T. - Bács, Z. - Kovács, D.: Comparative analysis for the practical practice of cost calculation, EINCO Congress, Oradea, (2015).

4. Kiss, Á., Evaluation of the characteristics of goodwill in IFRS. The Annals of the University of Oradea. Economic Sciences, Tom XXIII, 1st Issue, pp.649-658, (2014).

5. Krishnamoorthy, V. - Carvalho, A. Discover SAP, 3rd edition, Galileo Press, (2013).

6. Laáb Á., Döntéstámogató vezetői számvitel, Complex Kiadó, Budapest, (2011).

7. Lakatos L. P. - Kovács D. M. - Madarasiné Szirmai A. - Mohl G. - Rózsa I. A Nemzetközi Pénzügyi Beszámolás Standardok elmélete és gyakorlata. Magyar Könyvvizsgáló Kamara, Budapest, 43-293 p. (ISBN: 978 89934-0-3), (2013).

8. Regulation (EC) $1606 / 2002$ on the Application of International Accounting Standards, (2002). 